\title{
Aplinkos apsaugos raidos problema Lietuvoje
}

\author{
Valentina Tuskenyte், \\ Jonas Volungevičius \\ Vilniaus universitetas, \\ M. K. Čiurlionio g. 27, \\ LT-03101 Vilnius \\ El.paštas:valentina.tuskenyte@gf.stud.vu.lt; \\ jonas.volungevicius@gf.vu.lt
}

Tuskenytė V., Volungevičius J. Aplinkos apsaugos raidos problema Lietuvoje. Geologija. Geografija. 2015. T. 1(3). ISSN 23517549 .

Straipsnyje pateikiama skirtingų laikmečių autorių aplinkos apsaugos politikos veikimo diferenciacija ị teritorinę ir kokybinę aplinkos apsaugą. Taip pat pateikiama teritorinès ir kokybinès aplinkos apsaugos sampratos bei jų tarpusavio santykio apžvalga. Naudojantis Aplinkos apsaugos agentūros duomenų bazėmis, sudaromas kokybinès aplinkosaugos žemèlapis, kuris rodo 2015 m. Lietuvoje vykdomą aplinkos komponentų (oro, vandens, dirvožemio) stebėseną. Remiantis sudarytu žemèlapiu, šiame straipsnyje pristatomos galimos kokybinės aplinkosaugos Lietuvoje perspektyvos.

Raktažodžiai: aplinkosauga, kraštovaizdis, stebėsena, kokybinė, teritorinè

\section{IVADAS}

Aplinkos apsaugos mokslas, palyginti su kitais gamtos mokslais, yra dar labai jaunas. Ne viename literatūros šaltinyje minima, kad aplinkos apsaugą, kaip atskirą discipliną, imta diegti tik XX a. 6-7 deš., kai dèl beatodairiško ekonomikos augimo aplinkos teršimas pasiekẻ kritinę ribą, o nesiimant jokių veiksmų žmonijos egzistavimo tolesnis scenarijus būtų buvęs labai graudus (Šešelgis, 1991; Juknys, 2005). Būtent labiausiai ekonomiškai išsivysčiusiose šalyse rūpestis aplinkos apsauga pasijuto pirmiausiai. Nuo šio šimtmečio II pusès vis intensyviau pradedamos rengti įvairios aplinkos apsaugos programos, tobulinami istatymai, normatyviniai dokumentai, suvokta, kad pagrindinius aplinkos komponentus - orą, vandenị, dirvožemí, biotą - reikia nuosekliai ir sistemingai stebèti. Pirmoji aplinkos būklès stebejimo, kontrolès ir ìvertinimo sistema pradèta kurti po Antrojo pasaulinio karo, 1970 m., kada visame pasaulyje dèl pramonès plètros atsirado realus pavojus gamtinès aplinkos kokybei: gamtinių išteklių pereikvojimui, cheminių medžiagu taršos didejimui (Daubaras ir kt., 2000). Lietuvoje taip pat po Antrojo pasaulinio karo buvo pradèti aplinkos kokybės stebejimai. Iki Nepriklausomybès aplinkos būklès stebèjimai buvo integruojami i vieningą sąjunginę monitoringo sistemą. Atkūrus Nepriklausomybę, vadovaujant tuometiniam Lietuvos gamtos apsaugos komitetui, buvo priimtas nutarimas „Dèl kompleksinio ekologinio monitoringo organizavimo ir gamtos aplinkos būklès faktografinès informacinès sistemos „Ekologija" sukūrimo" (Daubaras ir kt., 2000, 296 p.). Lietuvoje dèl vis atsirasdavusių pokyčių aplinkos apsaugos organizacineje struktūroje aplinkos monitoringo sistemai izsitvirtinti buvo labai sunku. 1991-1992 m. tuometinis Aplinkos apsaugos departamentas (atsirado reorganizavus Gamtos apsaugos komitetą) parengè, o $1993 \mathrm{~m}$. patvirtino naująją Lietuvos ekologinio monitoringo sistemą, kuri su tam tikrais pataisymais ir modifikacijomis gyvuoja iki dabar (Daubaras ir kt., 2000). 
Lietuvos aplinkos kokybės stebėsenos sistema yra mažai analizuota. Skirtingi autoriai tik pateikia esminius stebejjimo principus, tikslus, uždavinius, pristato, kokie parametrai buvo stebimi. P. Mierauskas (1996) daugiausia demesio skiria aplinkos apsaugos raidai, jis plačiau aprašo, kaip yra vykdomas pats stebejjimas, kokie parametrai yra matuojami. D. Butkus (2008) taip pat iš esmès rašo apie matuojamus rodiklius, tačiau lygina pasaulio ir Lietuvos mokslininkų informaciją apie aplinkos būklę, kaupimo būdus. R. Junkys (2005), kaip ir kiti minèti autoriai, smulkiai aprašo vykdomą atskirų aplinkos komponentų stebejjimo sistemą, tačiau labiau yra akcentuojami pagrindiniai valstybinio monitoringo bruožai. Stebėsenos tinklo raidos analizę nagrinèjo A. Daubaras, J. Dubra ir S. Motiejūnas (2000), tačiau jų aprašoma raida ties $1999 \mathrm{~m}$. ir baigiasi. Informacija, kaip vystėsi stebėsenos sistema po 1999 m. rasti galima skirtinguose Aplinkos ministerijos, Lietuvos geologų tarnybos leidiniuose (žr. lit. sąraše: 2, 7, 8, $12,18,19,23,24)$, tačiau ir ten pristatomas tik pats tinklas, neatliekama jokia jos efektyvumo kritinè analizè. Būtent dèl to, kad sistema nuolatos buvo tik pristatoma supažindinant su jos veikimo principais, tačiau neatliekant jokios analizès, šiame straipsnyje yra siekiama kuo išsamiau ne tik pristatyti tinklo raidą iki 2015 m., bet ir atlikti jos kritinę rekomendacinę analizę. Galbūt dèl to, kad tiek pats aplinkos apsaugos mokslas, tiek ir pati kokybiné aplinkos apsauga pradejo formuotis dar visai nesenai, detaliau juos pažinti reikalingi išsamesni metamoksliniai tyrimai.

Lietuvos aplinkos apsaugos sistemos analizeje akcentuojama kokybinè aplinkos apsauga, tačiau mažai demesio skiriama jos bendros struktūros analizei, kokybinès ir teritorinès aplinkos apsaugos tarpusavio santykiams nagrinèti, raidos tendencijoms apžvelgti.

Aplinkos apsaugos raidos analizè atskleista naudojantis skirtingais moksliniais leidiniais, knygomis, metinèmis stebėseną vykdančių institucijų ataskaitomis, buvo surinkta informacija apie stebẻsenos tinklo raidą Lietuvoje ir esamą padètį. Naudotasi jau susistemintais kartografiniais duomenimis, beveik visi jie buvo renkami iš Aplinkos apsaugos agentūros elektroninès duomenų bazès, taip pat naudotasi Lietuvos geologijos tarnybos tinklapyje esančiomis kartoschemomis, buvo sudarytas kompleksinis kokybinès aplinkosaugos žemèlapis.

\section{KOKYBINĖS APLINKOS APSAUGOS VIETA BENDROJOJE JOS SAMPRATOJE}

Pagal Lietuvos Respublikos aplinkos apsaugos įstatymą (2005), aplinkos apsauga - aplinkos saugojimas nuo fizinio, cheminio, biologinio ir kitokio neigiamo poveikio ar pasekmių, atsirandančiu igyvendinant planus ir programas, vykdant ùkinę veiklą ar naudojant gamtos išteklius. Iš jo matyti, kad vadovautis aplinkosauginiais principais iš esmès privalu beveik visoms sritims. Tačiau pačia gamtos apsauga (ką jau kalbèti apie aplinkos komponentų apsaugą) susirūpinta palyginti neseniai, ir pati sistema yra dar labai jauna, todèl ji aktuali išlieka kasdien. Maždaug prieš 40 metų aplinkos apsauga isitvirtino tiek politiniame, tiek visuomeniniame gyvenime (Balevičius ir kt., 2000). Didejjant gyventojų skaičiui sparčiai augo globalios aplinkos kaitos problemos, kurios mūsų planetoje susijusios su pokyčiais biosferoje, stipriai užterštu oru, vandeniu, dirvožemiu, senkančiais naudingụjų iškasenu šaltiniais. K. Šešelgis (1991) atkreipia dèmesị i tai, kad „XX amžiaus viduryje iš esmès pakito požiūris i žmogaus ir gamtos santykius. Nuo gamtos valdymo idejos pastaruoju metu pereinama prie visuomenès ir gamtos, kaip lygiu partnerių, sandraugos idejos". Toks požiūrio kitimas buvo nulemtas įvairių veiksnių: padidejusio užterštumo, ligų, sumažejjusio derliaus ir kt. Požiūrio kitimas sukūrè prielaidas rastis aplinkos apsaugai ir Lietuvoje. Tačiau mūsų šalyje vykdomą aplinkos apsaugos politiką iki pat $1988 \mathrm{~m}$. labiau tiko vadinti gamtos apsauga. Kompleksiškai ir sistemingai saugoti ir tausoti mus supančią aplinką pradèta $1990 \mathrm{~m}$. balandžio $5 \mathrm{~d}$., kai buvo ¡kurtas Lietuvos Respublikos aplinkos apsaugos departamentas, nulèmęs aplinkos apsaugos veiklos diferencijavimą. Atskiros institucijos rūpinosi aplinkos ir gamtos komponentų apsauga bei stebejimu. Tam ittakos galejo turèti ne tik naujai sukurta, aplinkos apsaugos politiką kuruojanti institucija, tačiau vis didejjantis susirūpinimas aplinkos tarša. Aplinkos apsaugos administravimo raidoje vis sistemingiau buvo dalomos jos veiklos sritys. Aplinkos ir gamtos apsaugos klausimais rūpinosi skirtingi Aplinkos apsaugos ministerijos padaliniai. Praeities ịvykiai aiškiai rodo, kad vis dèlto aplinkos apsauga suprantama kaip vientisa sistema, tačiau ji veikia dviem pagrindinemis kryptimis: aplinkos parametrų (kokybinè aplinkos apsauga) ir jos komponentų (teritoriné aplinkos 
apsauga) apsauga. Tarp mokslininkų vis dažniau girdimas aplinkos apsaugos skirstymas $\mathfrak{i}$ aplinkos ir gamtos apsaugą, kaip i dvi atskiras, tačiau tarpusavyje susijusias sritis. P. Kavaliauskas (2012) skiria dvi aplinkos apsaugos veikimo politikos kryptis: kokybinę ir teritorinę aplinkos apsaugą. R. Baškytė (2013) taip pat skiria Lietuvoje egzistuojančią aplinkos apsaugą $\mathfrak{i}$ dvi dalis: atskirai aplinkos apsauga ir gamtos apsauga, K. Šešelgis (1991) irgi aiškino skirtumus tarp aplinkos ir gamtos sampratų, taip pat ir jų apsaugos. Remiantis šių autorių mintimis, itvirtintu istatymu, galima teigti, kad dabartinè aplinkos apsaugos samprata nèra visiškai nusistovejusi, dèl to nèra ịtvirtintas ir aiškus jos diferencijavimas. Dalant aplinkos apsaugą ì kiekybinę ir kokybinę atsiranda problemų, nes šios dvi apsaugos kryptys neretai persipina. Kiekybineje (teritorinejje) aplinkos apsaugoje dažnai yra naudojami kokybinès aplinkos apsaugos metodai. Kokybinę aplinkos apsaugą tampa vis sunkiau atskirti nuo teritorijos kiekybinių parametrų apsaugos. P. Kavaliauskas (2012) kokybinę aplinkos apsaugą apibrèžia taip: oro, vandens kokybès apsauga, atliekų tvarkymas, aplinkos apsauga nuo fizikinès taršos. Teritorinès aplinkos apsaugos samprata, P. Kavaliausko (2012) teigimu, apima „kraštovaizdžio, miškų, rekreacinès aplinkos apsaugą, saugomų teritorijų sistemos tobulinimą, gamtinių išteklių valdymą“. Mokslininko issitikinimu, kokybinès aplinkos apsaugos samprata visuomenei yra geriau žinoma, ja labiau domimasi. Nors teritorinè aplinkos apsauga išlieka svarbi visoje aplinkos apsaugos veikimo politikoje, tačiau ja mažiau domimasi. Anot P. Kavaliausko, viena iš priemonių teritorinei aplinkos apsaugai formuotis ir igyvendinti galètų būti kraštovaizdžio politikos formavimasis, nes teritoriné aplinkos apsauga yra glaudžiai susijusi su kraštovaizdžiu kaip erdvè, kurioje ji yra realizuojama.

Aplinkos apsaugos veikimo sistemą ì dvi dalis skiria ir R. Baškytè (2013). Autorè remiasi K. Šešelgio darbais, kaip galimais kokybinès aplinkos apsaugos sampratos pirmtakais. R. Baškytè teigè, kad jei gamtos apsaugos samprata apima „žmonių sveikatos apsaugą nuo kenksmingų tiesioginio ar netiesioginio ūkinès veiklos poveikio padarinių“, tai tokia gamtinès apsaugos samprata priarteja prie aplinkos apsaugos sampratos (Baškyte, 2013). Mokslininke aplinkos apsaugos veikimo politiką $\mathfrak{i}$ dvi dalis skiria vadovaudamasi kraštovaizdžio ir aplinkos sampratų skirtumais. Jei aplinkos apsaugą traktuosime kaip kraštovaizdžio sampratą, tai ji bus suprantama kaip teritoriné aplinkos apsauga. Jei ị ją žvelgsime per aplinkos kokybinius parametrus, ji bus įvardijama kaip kokybinè. Teritorinès aplinkos apsaugos samprata tapatinama su kraštovaizdžiu, kai kokybinès aplinkosaugos koncepcija, nors ir yra žinomi visi jos komponentai, vis dar lieka neaiški ir konkrečiai neapibrèžta:

- pagal Saugomų teritorijų ìstatymą (Lietuvos Respublikos saugomu..., 2001), kraštovaizdis - tai „Žemès paviršiaus gamtinių (paviršinių uolienų, pažemio oro, paviršinių ir gruntinių vandenų, dirvožemio, gyvųjų organizmų) ir (ar) antropogeninių komponentų (archeologinių liekanų, statinių, inžinerinių įrenginių, žemès naudmenų bei informacinio lauko), susijusių medžiaginiais energetiniais ryšiais, teritorinis junginys" (Baškyte, 2013, p. 226);

- „Kraštovaizdžio bendrojo supratimo pamatas yra mokslinè paradigma apie visų Žemès paviršiaus abiogeninių, biogeninių ir sociogeninių (antropogeninių, technogeninių) komponentų erdvinę integraciją ir šio proceso désningą teritorinę raišką, igalinančią skirti kraštovaizdžio struktūros ịvairovę atspindinčius jo teritorinius kompleksus" (Kavaliauskas, 2011, p. 5);

- pagal šiuo metu Lietuvoje juridiškai įteisintą aplinkos apibrèžimą, „aplinka - gamtoje funkcionuojanti tarpusavyje susijusių elementų (žemès paviršiaus ir gelmių, oro, vandens, dirvožemio, augalų, gyvūnų, organinių ir neorganinių medžiagų, antropogeninių komponentų) visuma bei juos vienijančios natūraliosios ir antropogeninès sistemos" (Lietuvos Respublikos aplinkos..., 2005).

Jeigu į aplinkos apsaugą žiūrima kaip ị kraštovaizdị, formuojasi skirtinga aplinkos samprata, tačiau R. Baškyte pripažista, kad Lietuvoje šios sampratos viena kitą papildo, aplinka - daugiau ekologinè sąvoka, kraštovaizdis - geografinis terminas. Tačiau kalba eina apie tą pati objektą. Kraštovaizdžio termino atveju akcentuojami mus supančios aplinkos komponentai ir jų teritorinès struktūros; aplinkos termino atveju akcentuojamos ją sudarančių komponentų kokybinès charakteristikos. Taip pat reiktų atkreipti demesị $\mathfrak{i}$ tai, kad kraštovaizdis - aplinka siauraja prasme, aplinkos dalis apribota kraštovaizdžio sampratos. Kita vertus, plačiaja prasme aplinka - tai mus supanti geografinè sfera (žr. 1 pav.). Žvelgiant $\mathfrak{i}$ aplinkos apsaugą kaip $\mathfrak{i}$ geografinę aplinkos pažinimo bei kraštotvarkinę veiklos joje reguliavimą, objektu siaurąja prasme turètų būti 


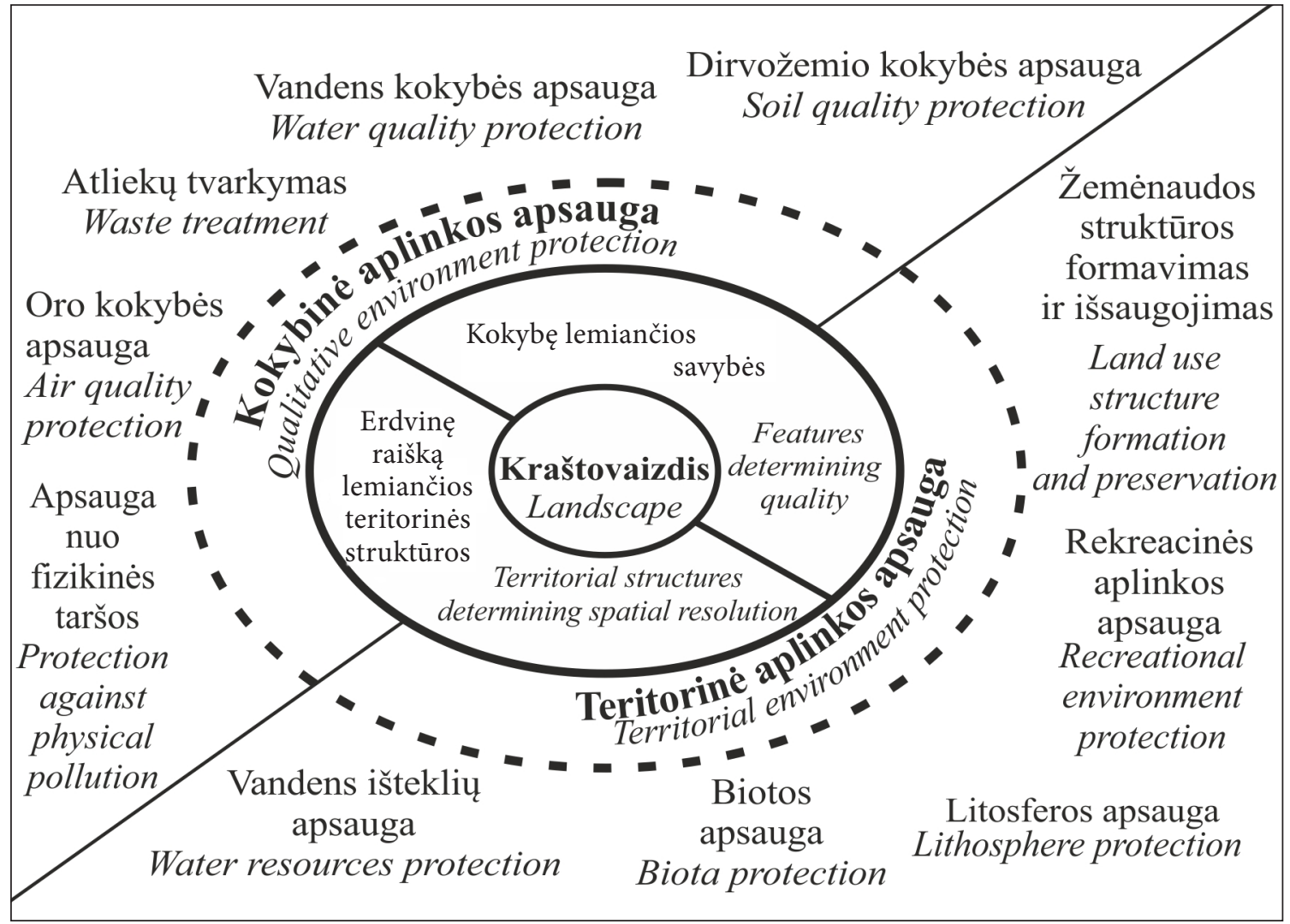

1 pav. Aplinkos apsaugos samprata kraštovaizdžio kontekste

Fig. 1. Environmental protection in the context of landscape

ivardijamas kraštovaizdis, o plačiaja prasme - geografinè sfera. R. Baškytè (2013) patvirtina ir P. Kavaliausko (2012) aplinkos apsaugos skirstymą i kokybinę ir teritorinę. Skiriasi tik pavadinimai: kokybiné - aplinkos apsauga, o teritoriné - gamtos apsauga. „Gamtos, gamtinès aplinkos apsauga yra orientuota i gyvosios ir negyvosios gamtos, gamtinio kraštovaizdžio išsaugojimą, o aplinkos apsauga - $\mathfrak{i}$ fizinès, cheminès, biologinès ir kitokios taršos sumažinimą" (Baškyte, 2013, p. 227). Šiuose apibrèžimuose nèra minima gamtos išteklių apsauga, kultūrinès aplinkos apsauga todèl, kad apskritai įvairiose šalyse šių dviejų elementų apsauga yra priskiriama kokybinei aplinkos apsaugai (aplinkos apsaugai), o kai kur - teritorinei (gamtos apsaugai). Lietuvoje gamtos išteklių, kultūrinè aplinkos apsauga skirstoma tiek $\mathfrak{i}$ kokybinę, tiek ir $\mathfrak{i}$ teritorinę aplinkos apsaugą. Autorè teigia, kad, pavyzdžiui, „...vandens išteklių apsauga priskirta aplinkos apsaugai, gyvūnijos išteklių apsauga - gamtinès aplinkos apsaugai“.

Kodèl yra būtinas aplinkos apsaugos diferencijavimas i kokybinę ir teritorinę? Dabar aplinkos apsaugos politiką formuoja Seimas, o tiesiogiai atskiras šios politikos sritis kuruoja Seimo aplinkos apsaugos komitetas, formuojamoje politikoje nèra išskiriama kokybine ir teritorinè aplinkos apsauga, nors pateikiama per 16 ịvairių aplinkos apsaugai svarbių probleminių sričiu ir, kaip teigia P. Kavaliauskas (2012), tarp tų 16 probleminių sričių „išsibarsto teritorinès, o tame tarpe ir kraštovaizdžio apsaugos tikslai, už kurių igyvendinimą bei pačios kraštovaizdžio politikos tobulinimą ir jos igyvendinimo priežiūrą yra atsakinga Aplinkos ministerija“ (Kavaliauskas, 2012, p. 89).

Apjungus kraštovaizdžio ir aplinkos sampratas gaunamas platesnis ir aiškesnis kokybinès aplinkos apsaugos supratimas, kokybinè aplinkos apsauga - aplinkos ir kraštovaizdžio komponentu kokybès stebejjimų ir būklès užtikrinimas. „Teritorinè aplinkos apsauga - kraštovaizdžio, miškų, rekreacinès aplinkos apsauga, saugomų teritorijų sistemos tobulinimas, gamtinių išteklių valdymas“ (Kavaliauskas, 2012) (žr. 1 pav.). Taigi, norint optimizuoti aplinkos apsaugos priemonių igyvendinimą ir aplinkos kokybės gerinimą reikètų kokybinès ir teritorinès aplinkos apsaugos sampratas iteisinti teisès aktuose. Taip pat išsamiau išanalizuoti jų tarpusavio sąsajas. 


\section{KOKYBINĖS APLINKOS APSAUGOS TERITORINE் DIFERENCIACIJA}

Lietuvoje stebėsenos programos rengti pradètos palyginti vèlai. Iki atkuriant Nepriklausomybę Lietuva ilgą laiką priklausẻ Sovietų Sąjungai, stebėsenos sistema tik iš dalies atstovavo kokybinei aplinkos apsaugai. Oro, vandens stebejjimai ne visada buvo reguliarūs, sisteminiai, o dirvožemio stebėsenos bei atliekų tvarkymo klausimai buvo aktualūs tik tiek, kiek tai buvo svarbu norint pakelti ūkio našumą (Daubaras ir kt., 2000). Situacija pradèjo gerèti maždaug nuo $1991 \mathrm{~m}$., Lietuvai tapus savarankiška valstybe. Kokybinès aplinkos apsaugos tinklas kito ir kinta iki šiol.

Pagrindinès kitimo priežastys iki $2001 \mathrm{~m}$. buvo institucijų, atsakingų už stebėseną, prerogatyva - pavaldumo kaita, finansavimas, tarptautinis bendradarbiavimas, suteikęs žinių apie kitose valstybèse taikomas stebėsenos programas, ir ateinantis gilesnis aplinkos komponentu svarbos suvokimas, praeityje paliekamas žmogaus noras išnaudoti gamtą (Daubaras ir kt., 2000). Anot R. Juknio (2005), $2001 \mathrm{~m}$. stebèsenos tinklo kaitai nemažai įtakos turejo įstojimas ị Europos Sąungą, nes, tapus jos nare, šalyje vykdoma aplinkosaugos politika rèmèsi ir remiasi ES patvirtintomis direktyvomis, sprendimais ir kitais teisès aktais.

Lietuvos kokybinès aplinkos apsaugos sistemą sudaro oro, vandens, dirvožemio stebèsena ir atliekų tvarkymas. Kokybinès aplinkos apsaugos (stebèsenos) organizacinè struktūra šiuo metu yra vykdoma trimis lygmenimis: stebèsena - valstybiniu lygmeniu; toliau eina savivaldybių lygmuo - čia vykdoma aplinkos komponentų stebėsena; ir ūkio subjektų, kurių veikla gali kaip nors pakenkti kuriam nors aplinkos komponentui ar jų grupei - vandeniui, orui, dirvožemiui (Lietuvos Respublikos aplinkos..., 1997). Valstybinis aplinkos kokybès stebèsenos lygmuo, apimantis visą šalies teritoriją, yra plačiausiai ir nuosekliausiai išplètotas, todèl ji nagrinejant labiausiai atsiskleidžia aplinkos komponentų būklès kontrolès ištyrimas. Savivaldybių vykdoma stebèsena yra fragmentiška. Šiuo metu tik 8 savivaldybès yra parengusios papildomas stebèsenos programas. Stebėsenos vykdytojai, priklausomai nuo stebimo aplinkos komponento, taip pat skiriasi. Šiuo metu didžiąją dali stebėsenos tyrimų atlieka Aplinkos apsaugos agentūra, jai pavesta paviršinio vandens (upių, ežerų, Kuršių marių ir Baltijos jūros) stebèsena, aplinkos oro stebėsena, atliekų tvarkymo sistema, taip pat ji kuruoja KMS stočiu darbą. Lietuvos geologijos tarnybai pavesta vykdyti požeminio vandens, laukų dirvožemio stebėseną, o Valstybinei miškų tarnybai - miškų dirvožemio.

Kokybinès aplinkos apsaugos tinklą iš viso sudaro 3613 stebèsenos stotys ( $2015 \mathrm{~m}$. duomenys). Didžiąją dalị tinklo sudaro požeminio (2 590) ir paviršinio (838) vandens monitoringas. Oro monitoringo tinklą sudaro 36, dirvožemio - 67 (miškų) ir 71(laukų), kompleksinio monitoringo (toliau - KMS) - 2 stotys, atliekų tvarkymo punktų šalyje - 13 (̌̌r. 2 pav.).

Daugiausia požeminio vandens stebėsenos stočių yra Ignalinos ir Mažeikių rajonų savivaldybėse, bei Vilniaus miesto savivaldybès teritorijoje. Tokiam dideliam stebejjimo stočiu skaičiui įtakos turi: Ignalinos r. sav. teritorijoje esanti uždaryta atominè elektrinè, Mažeikių r. sav. teritorijoje vykdoma intensyvi pramoninè veikla, o Vilniaus miestas išsiskiria savo urbanizuotos teritorijos dydžiu ir gyventojų skaičiumi. Vidurio Lietuvoje požeminio vandens stebèsenos stočių intensyvumas - vidutiniškas, o mažiausia šių stočių yra Klaipedos miesto, Skuodo, Kretingos, Rietavo, Raseinių, Ukmergès, Širvintų, Kazlų Rūdos, Birštono, Šalčininkų ir Švenčionių rajonų savivaldybèse (žr. 2 pav.).

Šiuo metu Lietuvoje iš viso yra 838 paviršinio vandens kokybès stebejimo stočių. Remiantis 2011-2017 m. valstybine monitoringo programa, paviršinio vandens stebėsena yra vykdoma pagal keturias kategorijas. 2015 m. šalyje buvo 66 priežiūros intensyvios stebėsenos stotys, 326 ekstensyvios, 409 veiklos ir 42 tiriamosios stebèsenos (Valstybiné aplinkos monitoringo..., 2010). Paviršinio vandens būklès stebėsenai vertinti vykdomos priežiūros (intensyvios, ekstensyvios), veiklos ir tiriamosios stebėsenos stotys yra labai netolygiai pasiskirsčiusios Lietuvos savivaldybèse, intensyviausia stebėsena atliekama ežeringiausioje Lietuvos teritorijos dalyje, šiaurès rytuose, vidutiniškai - pietuose bei Vidurio Lietuvoje, o mažiausia stebimos Jonavos, Rietavo ir Šilalès rajonų bei didžiųjų miestų savivaldybès (žr. 2 pav.).

Lietuvoje oro stebėsenos tinklas apima ne visas šalies savivaldybes. Stebėsenos stotys, matuojančios transporto, pramonès, miesto foninę oro būklę, yra ịkurtos Vilniaus, Kauno, Panevėžio, 


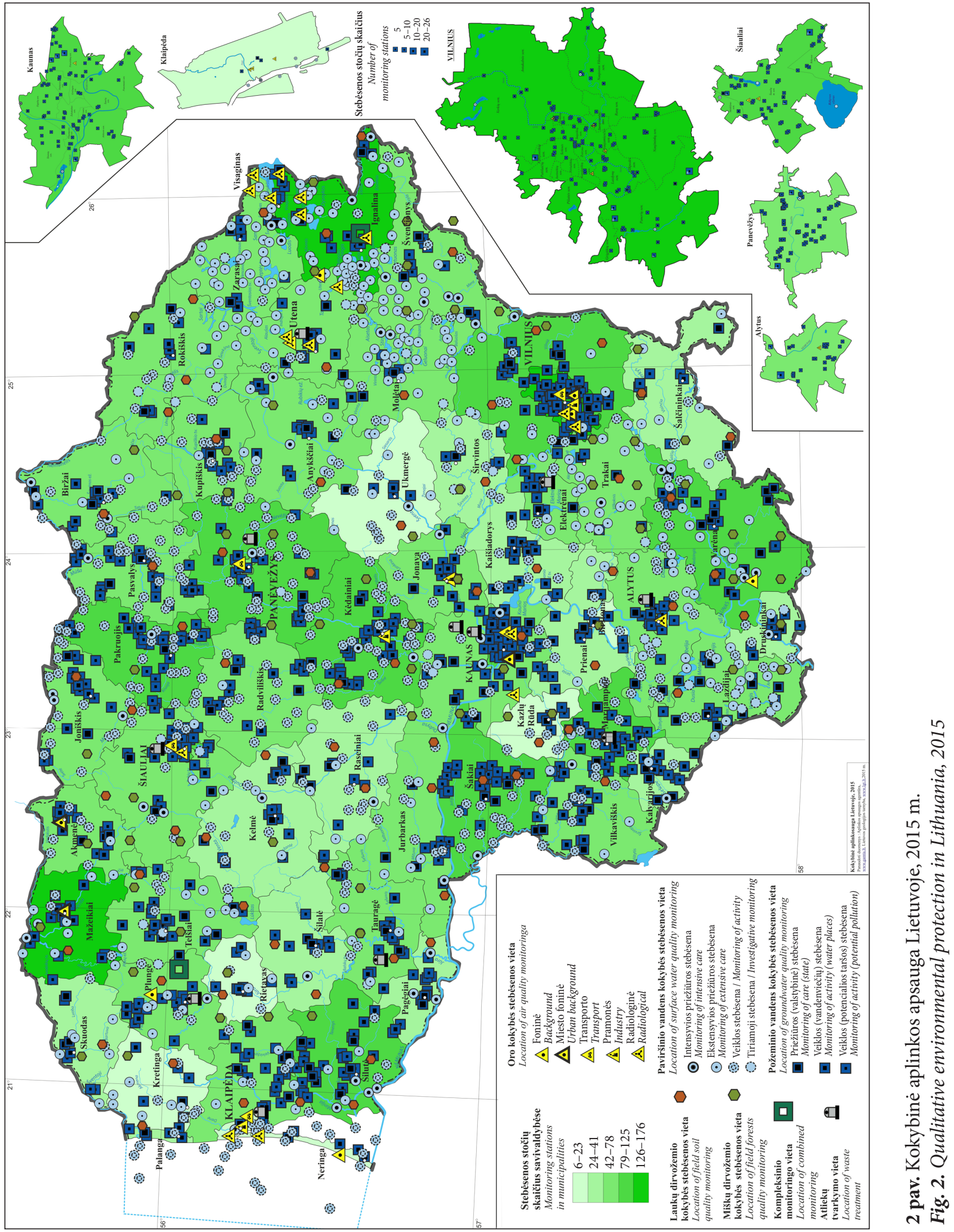


Šiaulių, Klaipedos miestų savivaldybėse, taip pat Jonavos, Kèdainių, Mažeikių ir Akmenès rajonų savivaldybėse. Tokị stočiu pasiskirstymą lemia naujai pradèti oro kokybès stebejimai aglomeracijose ir zonose, taip pat tai, kad stebimi didieji miestai, didesni pramonès centrai. Keturios foninio oro stebejimo stotys yra ikurtos Utenos ir Varénos rajonuose, Neringos miesto ir Plungès rajonų savivaldybėse. Tokị jų išdėstymą lemia tai, kad stebèsenos stotys, norint gauti kuo tikslesnius duomenis, yra įrengtos žmogaus mažiausia veikiamoje aplinkoje - nacionaliniuose parkuose. Radiologinès stebėsenos stočiu daugiausia yra Utenos, Ignalinos ir Zarasų rajonų savivaldybèse. Šios savivaldybès pasirinktos todèl, kad jų kaimynystejje anksčiau veikè Ignalinos atominè elektrinè. Radiologinio oro stebėsenos stočių taip pat yra Vilniaus, Kauno, Alytaus, Šiaulių ir Klaipèdos miestų savivaldybėse (žr. 2 pav.).

Dirvožemio stebėsena $2015 \mathrm{~m}$. Lietuvoje vykdoma 138 stotyse: miškų - 67, laukų - 71. Daugiausia stebimi derlingiausi Lietuvos dirvožemiai: Kèdainių ir Marijampolès rudžemių bei išplautžemių rajonas, Šiaulių ir Panevėžio rudžemių rajonas, o mažiausia - Šventosios ir Nidos smèlžemių rajonas. 2016-2018 m. yra rengiama nauja miškų dirvožemio stebėsenos programa. Stebèjimų aikštelès išdèstytos pagal Europos tinklo aikštelių reikalavimus - $9 \times 9 \mathrm{~km}$, yra 81 nauja stebèsenos aikštelè (senosios aikštelès buvo išdèstytos pagal Sovietų Sąjungos reikalavimus, todèl yra korektiškai nesistemingos).

Lietuvoje viena iš opiausių aplinkos apsaugos problemų - atliekų tvarkymas. Nors ịstojus ị Europos Sąungą situacija šiek tiek pagerèjo, tačiau problemų vis dar yra. 2003 m. Lietuvoje vienas iš aplinkos apsaugos politikos prioritetų - sąvartynų skaičiaus mažinimas. 2001 iki 2003 m. jų skaičius sumažèjo, tačiau nepakankamai - nuo beveik 800 (2001) iki 737 (2003), tiesa, tais pačiais metais buvo uždaryti 42 sąvartynai. Keltas tikslas - iki $2009 \mathrm{~m}$. Lietuvoje palikti 1 pavojingų atliekų sąvartyną ir 10 regioninių sąvartynų (Aplinkos būklè, 2004). Deja, šis tikslas tik iš dalies pasiektas kiek vèliau nei buvo planuota - 2015 m., Aplinkos apsaugos agentūros duomenimis, Lietuvoje tebeveikia 11 sąvartynų, iš kurių 3 yra skirti pavojingoms atliekoms (žr. 2 pav.).

Kompleksinio monitoringo sistema (KMS) - tai integruotas aplinkos parametrų stebejimas. 1992 m., po Nepriklausomybės atkūrimo, Šiaurès šalių Ministrų Taryba pasiūlè Lietuvai prisijungti prie tarptautinès kompleksiško monitoringo programos ICP IM. Lietuvai prièmus siūlymą, jau $1993 \mathrm{~m}$. pagrindiniuose Lietuvos žemèvaizdžiuose ikurtos dvi ISM stotys: Aukštaitijos ir Dzūkijos nacionaliniuose parkuose. Ikuriant naujas stotis pagrindinis dèmesys buvo kreipiamas i tai, kad jos būtų mažiausio antropogeninio poveikio teritorijose. Taip pat svarbu buvo nepažeisti parko teritorijos, ikuriant stotis buvo atsižvelgiama $\mathfrak{i}$ tuometinę parkų infrastruktūrą. $1994 \mathrm{~m}$. ISM tinklą papildè dar viena stotis - Žemaitijos nacionaliniame parke (Salygiškai natūraliu ekosistemu..., 2006). Visos trys stotys gerai reprezentavo pagrindinius šalies kraštovaizdžio tipus. Jos buvo ịkurtos parkų rezervacinèse zonose, kur vyravo tiriamojo regiono miško tipai ir būdingiausios geomorfologinès struktūros bei augimvietès. Deja, nuo 1999 m. Dzūkijos KMS stoties darbas buvo nutrauktas (Sąlygiškai natūralių ekosistemų..., 2006). Tad nuo 1999 m. iki pat 2015 m. veikia tik dvi kompleksinio monitoringo stotys (žr. 2 pav.).

Bendras stebėsenos stočių intensyvumas Lietuvoje yra labai netolygus, stebejjimų gausa išsiskiria Ignalinos r. (176 stotys), Vilniaus miesto (168) ir Mažeikių r. (149) savivaldybès. Kaip jau buvo minèta anksčiau, tokiam stočių intensyvumo pasiskirstymui įtakos turèjo: Ignalinos r. sav. teritorijoje esanti uždaryta atomine elektrinè bei gausybė ežerų, Mažeikių r. sav. teritorijoje intensyviai vykdoma pramoninè veikla, o Vilniaus miestas išsiskiria savo urbanizuotos teritorijos dydžiu ir gyventoju skaičiumi. Šiek tiek mažiau, bet taip pat gausiai stebima: Kėdainių r. (117 stočių), Vilniaus r. (111), Šilutès r. (108), Varènos r. (98), Panevėžio r. (87), Šakių r. (86), Marijampolès r. (86) ir Pakruojo r. (85) savivaldybès. Mažiausias stebėsenos stočių skaičius Lietuvos teritorijoje yra penkiose savivaldybėse: Kretingoje r. (23), Ukmergeje r. (22), Rietavo (21), Kazlų Rūdos (17 ir Birštono (6). Toks stebėsenos stočių skaičius minètose savivaldybèse sietinas su silpnesniu urbanizacijos ir mažesniu pramonès objektų skaičiumi jose.

\section{KOKYBINĖS APLINKOS APSAUGOS RAIDOS PERSPEKTYVOS}

Lietuvos aplinkos apsaugos sistema išgyveno sudètingą raidą, kuri glaudžiai siejosi ir su pačios šalies socioekonominès raidos ypatumais, ir politinemis 


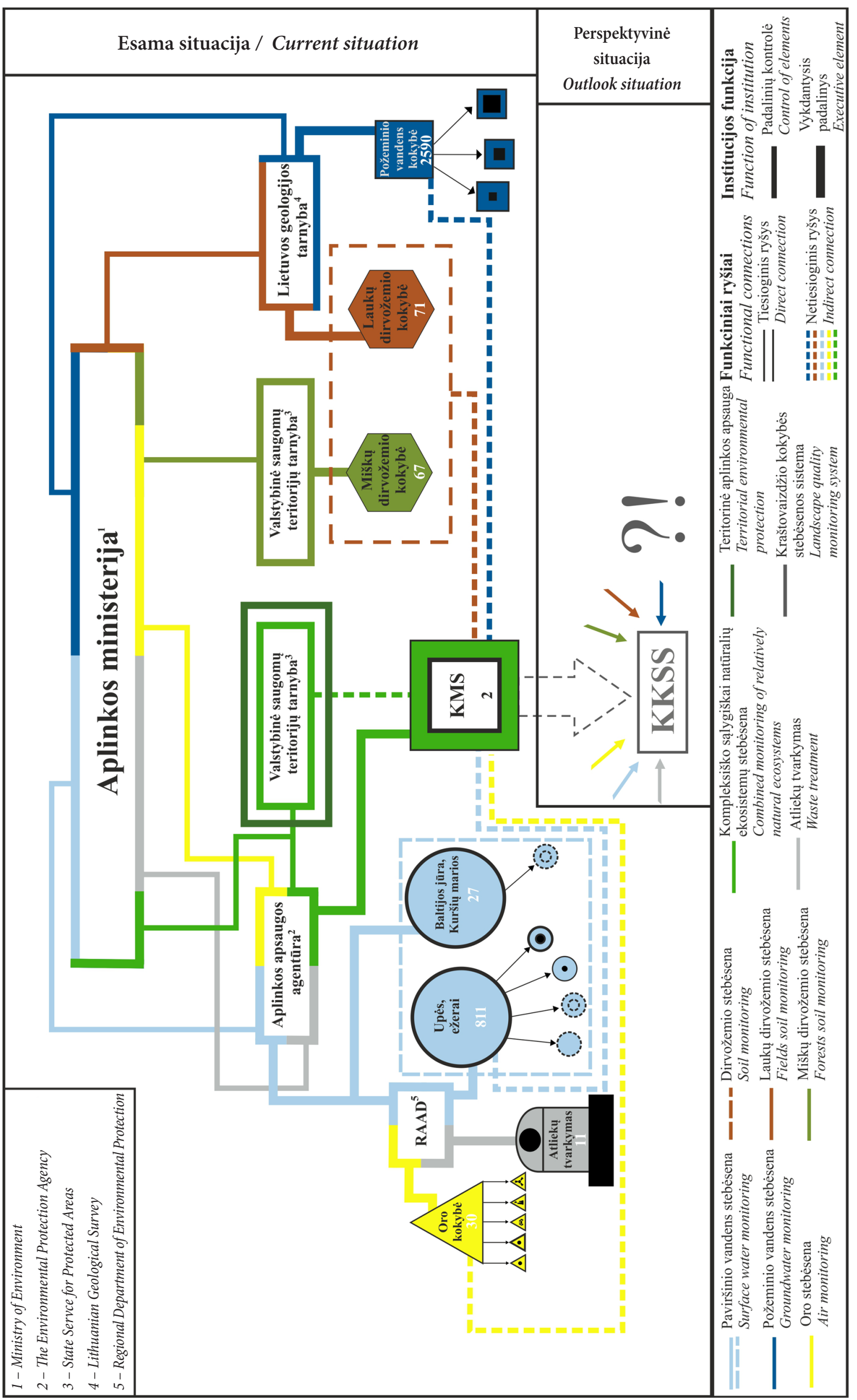

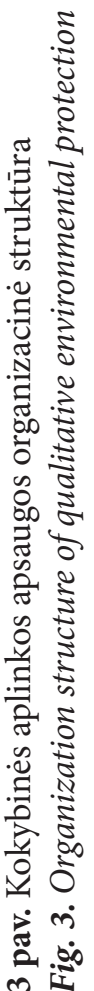


aktualijomis. Ivairiais laikotarpiais vyko skirtingos atskirų struktūrinių grandžių transformacijos. Dauguma jų buvo nukreiptos ị atskirų aplinkos apsaugos grandžių struktūros sudetingumą bei sistemos plètrą, funkcijų diferencijavimą. Šios raidos tendencijos lèmé, kad susiformavo stiprios, tačiau iš dalies viena nuo kitos atsietos, aplinkos apsaugos sistemos, orientuotos i kokybinių ir teritorinių aplinkos rodiklių užtikrinimą. Kadangi aplinkos kokybė ir jos rodiklių teritorinè diferenciacija yra tarpusavyje glaudžiai susijusi, susidariusi situacija apsunkina bendrosios aplinkos kokybės tikslų igyvendinimą bei silpnina sąsajas tarp kokybinès ir teritorinès aplinkos apsaugos sistemų.

Lietuvoje kokybinès aplinkos apsaugos sistemą sudaro aplinkos komponentų stebèsena: oro, vandens (paviršinio ir požeminio), dirvožemio bei atliekų tvarkymas (žr. 3 pav.), o teritorinei aplinkos apsaugai priskiriama kraštovaizdžio, augmenijos, gyvūnijos apsauga, apimanti saugomas teritorijas ir natūra 2000 teritorijų. Kai kurių iš komponentų (oro, vandens) stebèsenos sistemos yra itin gerai išplètotos (žr. 2 pav.). Kompleksiškai natūralių ekosistemų (KMS) stebėsena netiesiogiai apjungia šias dvi aplinkos apsaugos kryptis. Kadangi šiuo metu Lietuvoje yra veikiančios tik dvi šios stebėsenos stotys (Aukštaitijos ir Žemaitijos nacionaliniuose parkuose), nèra visiškai reprezentuojami pagrindiniai šalies kraštovaizdžio teritoriniai vienetai, nes stotys yra ikurtos tik dviejų parkų rezervacinèse zonose, kur vyrauja tiriamojo regiono miško tipai ir būdingiausios geomorfologinès struktūros augimvietès. Stebejjimų pobūdis priskirtas kokybinei aplinkos apsaugai, tačiau stebima teritorija yra teritorinès aplinkos apsaugos kuruojamoje teritorijoje, nacionaliniuose parkuose. Ir nors stebèsenos sistema sudètingèjo (žr. 3 pav.), dabartinè kokybinè aplinkos apsauga daugiausia yra orientuota $\mathfrak{i}$ skirtingu aplinkos komponentu stebėseną, bendroji aplinkos kokybès samprata silpnai išreikšta, išryškinta surenkama informacija apie tai, ar kokybiškas vanduo, oras, dirvožemis, tačiau nèra atsakoma ị klausimą, ar aplinka yra kokybiška, ar ne? Koks kokybės laipsnis? Aplinkos kokybès visuminio vertinimo kontekste KMS stočių sistemos tinklo plètra būtų tikslinga, jis ne tik apibendrintu aplinkos kokybès parametrus, sustiprintų sąsajas tarp kokybinès ir terito- rinès aplinkos apsaugos sistemų, bet ir atsakytu i anksčiau keltus klausimus, juos taip pat susietu su konkrečia teritorija. Šiu stočių tinklo tobulinimas suformuotu aplinkos apsaugos organizacinès struktūros trūkstamą integracinę grandị, jungiančią kokybinès ir teritorinès aplinkos apsaugos stebésenos sistemą. Tokia aplinkos kokybès stebėsenos sistema, susidedanti iš kokybinès, teritorinès aplinkos apsaugos ir aplinkos kokybès kompleksinio vertinimo sistemų, sudarytų prielaidas įvertinti visuminę aplinkos kokybę pagal jos ergonominius, bionominius, psichonominius, socionominius ir ekonominius parametrus. Tokia aplinkos apsaugos organizacinès struktūros vizija ne tik prisidètu prie aplinkos apsaugos sampratos tolimesnio plètojimo, tačiau sudarytų prielaidas (glaudžiai siejant su tvarios plètros principais) plètoti „Kokybiškos aplinkos" vertinimo rodikliu sistemą.

\section{IŠVADOS}

1. Aplinkos apsaugos organizacinè struktūra yra nuolatinès dinaminès būsenos, atspindinčios dabartinę visuomenès aplinkos ir jos kokybès sampratą. Aplinkos sampratos formavimas galètu būti priemonè tobulinant ar optimizuojant pačią organizacinę struktūrą.

2. Lietuvos aplinkos kokybės stebėsenos sistema yra netolygi, nulemta objektyvių aplinkos savybių ir subjektyvių visuomenès poreikių. Todèl stebésenos sistema atskirose jos grandyse atspindi tik jautriausią antropogeniniam poveikiui komponentų būklę.

3. Esama aplinkos kokybès stebėsenos sistema tik iš dalies atspindi visą aplinkos kokybès vaizdą. Tam, kad būtų užtikrintas visos aplinkos kokybès vertinimas kokybiniu ir teritoriniu aspektu, turètų būti plečiamas KMS stočių tinklas. Tai sukurtų prielaidas ergonominiu, bionominiu, psichonominiu, socionominiu ir ekonominiu aspektais igyvendinti aplinkos kokybę.

Gauta 20150921

Priimta 20151016

\section{LITERATŪRA}

1. Aplinkos apsaugos agentūra. Vandens telkiniu interaktyvus žemèlapis. http://gamta.lt (žiūrèta $20150123)$. 
2. Aplinkos būklè. 2004. Vilnius: Baltijos kopija.

3. Balevičius K., Jankevičius K., Liužinas R., Stasinas J. 2000. Valstybinis aplinkosaugos valdymas Lietuvoje. Kn.: Lietuvos aplinkosaugos raida. Vilnius: ABO.

4. Baškytė R. 2013. Lietuvos gamtinès aplinkos apsauga. Lietuvos gamtinè geografija. Klaipèda: KU l-kla.

5. Butkus D. 2008. Aplinkos monitoringas. Aplinkos apsauga. Vilnius: Technika.

6. Daubaras J. ir kt. 2000. Aplinkos monitoringas. Lietuvos aplinkosaugos raida. Vilnius: ABO.

7. Ežerų monitoringo 2010 metu planas. 2010. http:// gamta.lt (žiūrèta 201508 17).

8. Foninio oro ir sąlygiškai natūraliu ekosistemu monitoringo 2014 metu planas. 2014. http://gamta.lt (žiūrèta 201508 17).

9. Juknys R. 2005. Aplinkotyros mokslo ir studijų raida. Aplinkotyra. Kaunas: Morkūnas ir Ko.

10. Juknys R. 2005. Visuomenè ir aplinka. Aplinkotyra. Kaunas: Morkūnas ir Ko.

11. Kavaliauskas P. 2011. Kraštovaizdžio samprata ir planavimas. Kraštovaizdžio sampratos problema. http://www.vu.lt/ (žiūrèta 201509 03).

12. Kavaliauskas P. 2012. Nacionalinis kraštovaizdžio tvarkymo planas. Kraštovaizdžio apsaugos organizaciné struktūra. http://www.am.lt/ (žiūrèta 20150903 ).

13. Lietuvos gamtine aplinka būklè, procesai ir raida. 2013. Kaunas: KOPA.

14. Lietuvos požeminio vandens monitoringas 20052010 metais ir kiti hidrogeologiniai darbai. 2011. Vilnius: Lietuvos geologijos tarnyba.

15. Lietuvos Respublikos aplinkos apsaugos istatymas. Žin., 1992, Nr. 5-75.

16. Lietuvos Respublikos aplinkos monitoringo istatymas. Žin., 1997, Nr. 112-2824.

17. Lietuvos Respublikos saugomu teritoriju istatymas. Žin., 2001, Nr. 63-1188.

18. Mierakauskas P. 1996. Aplinkos monitoringas. Aplinkos apsauga. Vilnius: Enciklopedija.

19. Oro kokybès monitoringo aglomeracijose ir zonose 2014 metu planas. 2014. http://gamta.lt (žiūrèta 201508 17).

20. Radiologinio oro monitoringo 2010 metu planas. 2010. http://gamta.lt (žiūrèta 201508 17).

21. Sąlygiškai natūraliu ekosistemu kompleksiškas monitoringas. 2006. Vilnius: Lututè.

22. Šešelgis K. 1991. Aplinka ir žmogus. Aplinkos apsauga. Vilnius: Mokslas.

23. Valstybine aplinkos monitoringo 2011-2017 metuc programa. 2010. http://gamta.lt (žiūrèta 201508 17).

24. Tarpiniu vandenu monitoringo 2010 metu planas. 2010. http://gamta.lt (žiūrèta 201508 17).

25. Upių monitoringo 2010 metu planas. 2010. http:// gamta.lt (žiūrèta 201508 17).
Valentina Tuskenytė, Jonas Volungevičius

PROBLEM OF ENVIRONMENTAL PROTECTION DEVELOPMENT IN LITHUANIA

Sum mary

Environmental science is young and still developing. Environmental protection was started to install only in the twentieth century, sixth-seventh decade, when the indiscriminate growth of environmental pollution has reached a critical point. Therefore, the structure of this young science is still not perfect. Comprehensive and systematic monitoring of the environment in Lithuania began after the Second World War. After regaining independence in 1993, Lithuania adopted a new ecological monitoring system, which, with some adaptations and modifications, has been existing until now. The analysis of the system of environmental protection of Lithuania emphasizes qualitative ecology, but little attention is paid to the analysis of the structure, the relationship between the qualitative and territorial environmental protection and the review of trends in the evolution.

Holistic and systematic protection and conservation of the environment surrounding us started on 5 April 1990 when the Environmental Protection Department of the Republic of Lithuania was established, which originated differentiation of the environmental activities. During the development of the environmental protection administration, its areas have been distributed systematically, and different departments of the Ministry of Environment take care of the environment and nature. The events in the past show clearly that environmental protection is understood as an integrated system, but here it works in two main ways: environmental parameters (qualitative environment) and its components (territorial environment). It is more and more common among researchers to speak about the protection of the environment and nature as about two separate, but interrelated areas. P. Kavaliauskas defines the qualitative environment as follows: protection of air, water quality, waste management, environmental protection from physical contamination. The concept of the territorial environmental protection, according to P. Kavaliauskas, includes 'landscape, forest, recreational environmental protection, the improvement of the system of protected areas, the management of natural resources'. P. Kavaliauskas claims that as a legal tool for the development of the territorial landscape is the formation of landscape policy. By combining the concepts of landscape and environment a broader and clearer understanding of the environment can be gained. The qualitative environment protection contains environmental and landscape 
elements of quality assurance monitoring and condition. So, in order to optimize the implementation of environmental measures and the improvement of the quality of environment, qualitative and territorial environment concepts should be legalized, as well as more analysis of the links between them is necessary.

In Lithuania the qualitative monitoring of the environmental components of the environmental system consists of the following: air, water (surface, underground), soil and waste management and environmental landscape. The qualitative environmental network in Lithuania is composed of 3613 monitoring stations. Most of the network is composed of the underground (2 590) and the monitoring of the water surface (838). The total intensity of the stations in Lithuania is very uneven. Most of them are in Ignalina (176 stations), Vilnius (168 stations) and Mažeikiai (149 stations) municipalities. The minimum number of monitoring stations in Lithuania is in five municipalities: Kretinga (23 stations), Ukmergè (22 stations), Rietavas (21 stations), Kazlų Rūda (17 stations), and Birštonas (6 stations).
Complex monitoring of natural ecosystems (CMS) indirectly combines these two environmental trends. The nature of these stations is assigned to the qualitative monitoring of the environment, however, the observed areas are in the regions and national parks curated by the Territorial Environment Protection. Although the monitoring system is getting more and more complicated, the current quantitative ecology is focused on different components, and there is no common understanding of the quality. The information collected on the quality of water, air and soil is highlighted, but there is no answer to the question about the environment: Is it of good quality or not? In order to ensure the overall quality of the environment from qualitative and territorial dimensions, the CMS station network should be developed. Its development would create preconditions for the implementation of the total quality of the environment through its ergonomic, bionomic, psychonomic, socianomic and economic aspects.

Key words: environmental protection, landscape, monitoring, qualitative, territorial 